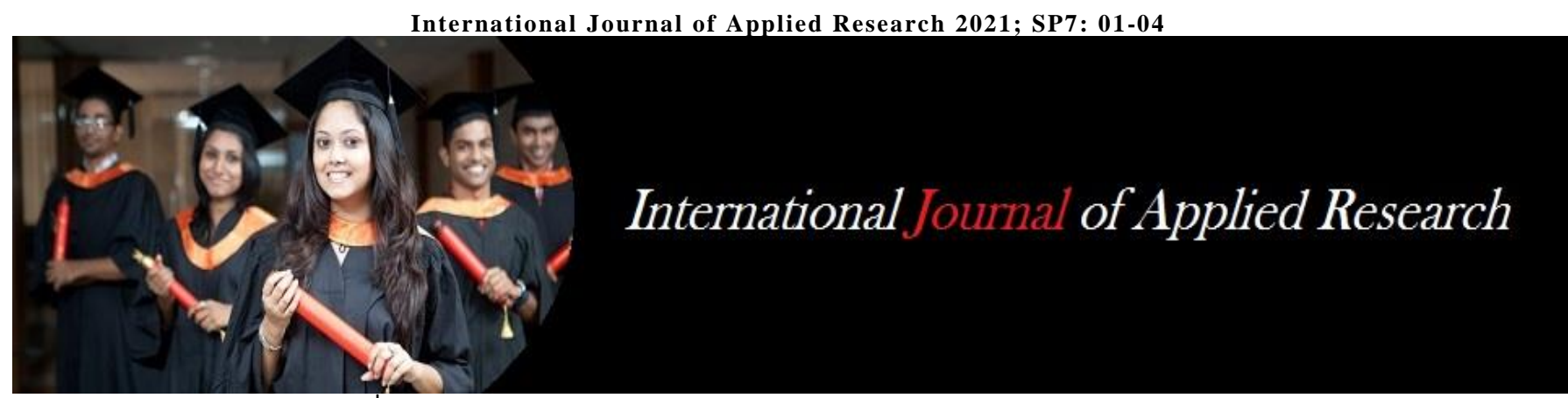

ISSN Print: $2394-7500$ ISSN Online: 2394-5869 Impact Factor: 8.4

IJAR 2021; SP7: 01-04

Dr. MD Masihur Rahman Assistant Professor,

Sukanta Mahavidyalaya Dhupguri, Jalpaiguri, West Bengal, India

Editors

Dr. Parmil Kumar

(Associate Professor),

Sahu Jain (P.G) College,

Najibabad (Bijnor), Uttar

Pradesh, India

Faiyazurrehman

(Research Scholar),

Dr. Bhimrao Ambedkar

University, Agra), Uttar

Pradesh, India

Dr. Anurag

(Principal),

Baluni Public School

Tallamotadak, Najibabad),

Uttar Pradesh, India
Correspondence

Dr. MD Masihur Rahman

Assistant Professor,

Sukanta Mahavidyalaya

Dhupguri, Jalpaiguri, West

Bengal, India.

\author{
(Special Issue) \\ "Twenty-First Century: Cultural and Economic Globalization"
}

\section{The Play of Biopolitics in Mahasweta Devi's Draupadi}

\author{
Dr. MD Masihur Rahman
}

DOI: https://doi.org/10.22271/allresearch.2021.v7.i7Sa.8652

\begin{abstract}
Critically considering the Agambenian status of "Camp (which) is the very paradigm of political space at the point of which politics become Biopolitics and Homosacer is virtually confused with the citizen" and the Foucauldian concept of Biopolitics -a system of regulation of the human body both biologically and politically, this article would like to explore the biopolitical praxis in Mahasweta Devi's Draupadi- a short story which tells about the explicit and exploitative representation of statesponsored violence and resistance to it by the subaltern representative. The state-sponsored violence and the activities of the rebels set in a fictional but politically reverberating setting is an attractive field of exploration. Looking at the short story through the Foucauldian and Agambenian concept of controlling Bios both biologically and politically, this article would like to assess the ways in which Biopolitics coerces the population. This article would like to explore the biopolitical subjugation of the subaltern and contributes to the discussion on Biopolitics.
\end{abstract}

Keywords: Biopolitics, Foucault, Agamben, State, coercion, incarceration, subaltern

\section{Introduction}

Biopolitics emerged in the 1970 s as a distinct sub-discipline in the powerful work of Michel Foucault who first extensively examined the power of the state over the individual as well as its citizens. Foucault used the term to denote the social and political power over life. Biopolitics signifies the strategies and mechanism which directly or indirectly manage /channelize the individual as well as the population under the regime of authority. Often political systems resort to surveillance, incarceration and killings in order to regulate the thought process of the population as well as individuals. Foucault felt the ever-increasing danger of "an omniscient government which conforms to the rule of right" (Foucault, 296). This omniscient government accomplishes what is dictated by the capitalist economy. He used the term "the polymorphous technique of power" (P-11)to express a particular phenomenon in the modern political context, to point out the confluence/ "deployment of power and knowledge" (P-73).

Political structures are moulded aiming at controlling people working at a different level. Foucauldian biopolitics concerns itself with such production and management of power. Such understanding expands the dictionary definition. According to Oxford English Dictionary, "Biopolitics is the interaction between politics and biology; specially politically motivated intervention in the growth and development of a population." Foucault expounds on the regulation of the population using various devices. Political belief /position determines the living condition of the population/individuals.

Giorgio Agamben's work is vitally important in the context of $20^{\text {th }}$-century Biopolitics"ModernBiopolitics: the politics of the great totalitarian states of the $20^{\text {th }}$ century (Agamben, p- 119). Agamben concentrates, as part of modern biopolitics, on bare life - a status in which the biological life of human beings becomes subject to political decisions and objectification. He observes how 'bare life' is subjected /projected to a status of exception - 
such status of exception - "constitutes rather a kinematic state, an emptiness of law" (Agamben, p-6). Various strategies are dexterously used to subjugate/regulate the population.

This article would explore the regulation of bodies in Draupadi in the context of Foucault's Founding concept of Biopolitics and Agamben's conceptualization of its modern version. Draupadi- an anglicized short story of Bengali playwright Mahasweta Devi - can be read as an aesthetic representation of modern Biopolitics. Focusing on the protagonist Draupadi this article would like to critically analyze the biopolitical perspective and contribute to the praxis of violence in contemporary society.

Modern Biopolitics: Bare life, state of exception: "Bare Life" points to a position - "a threshold of indistinction and of passage between animal and man, physis and nomos, exclusion and inclusion"(Agamben,P-105) it is a blurred threshold between human and non-human. At this blurred juncture, it is impossible to identify separately human/nonhuman. Agamben elucidates such status drawing a reference to Homosacer- a sacred man "who may be killed yet not sacrificed"(P- 8). The conception first existed in ancient Rome. Under Roman law, a person who committed a particular crime was exiled from society and all his civil rights were revoked. He thus was demoted to the position of Homosacer. As a result, he could be killed by anybody, while on the other hand he was deemed sacred. Roman citizen law is not applicable to such a person because of the application of another law. Homosacer has thus excluded from the law itself while being included at the same time. Hence Homosacer is a "double Exclusion into which he is taken and the violence to which he finds himself exposed" (Agamben, P-8). Again, while analyzing the "state of exception" he looks at how the killing of "bare life" is not considered homicide because it is considered sacred in a negative manner and is done under the dictate of sovereign political rule.

The modern kind of homosacer is found in 'camps' where the political prisoners are placed outside the rule of law(i.e. penal and prison law) and they are held captive without any right to normal judicial access. They are just incarcerated in prison. So, the camp is "the most absolute biopolitical space ever to have been realized in which power confronts nothing but pure life, without any mediation. This is why the camp is very paradigm of political space at the point of which politics became biopolitics and homosacer is virtually confused with the citizen" (Agamben,P-171).

While "prison law only constitutes a particular sphere of penal law and is not outside the normal order, the judicial constellation that guides the camp is (...) martial law and the state of siege". (Agamben, P-20)The state of siege refers to total coercion over the prisoners. In this context, Agamben puts a derogatory term 'muselmann' used by Nazi to exemplify the state of siege. The emaciated and starving captives of Nazi concentration camps resigned to their death due to inhuman torture making them unresponsive to their environment. According to Agamben these 'muselmann' captives are living a bare life- a living dead person, a status which is neither dead nor alive. 'bare life' is a state of exception. In a recent book, Agamben refers to the USA patriot act which 'erases' any judicial status of the captive, thus making the captive "a legally unnamable and unclassifiable being" (P-3). According to Agamben the captive Taliban in the context of the war in Afghanistan became "neither prisoners nor persons accused, but simply 'detainees', they are the object of pure de facto rule of a detention that is indefinite not only in the temporal sense but in its very nature as well, since it is entirely removed from law and from judicial oversight"'(P3-4). The concept of bare life/ state of exception would be elaborated in the context of 'Draupadi' which was written at the backdrop of the Naxalite movement.

The Naxalite Uprising: while addressing the nation Pundit Jawaharlal Nehru put emphasis on the all-around development of its people ensuring justice, equality, and democratic representation of all sections of life. He wanted to "bring freedom and opportunity to the common man, to the peasants and workers of India; to fight and end poverty and ignorance and disease; to build up a prosperous, democratic and progressive nation and to create social, economic, and political institutions which will ensure justice and fullness of life to every man and woman" (inc. in). Although he was willing to bring an all-pervasive development in the newly formed independent India, certain drawbacks stunted the growth and development.

Ranajit Guha explains this lack of care for all the people of India in his essay "On some aspects of Historiography of Colonial India" (in selected subaltern studies, ed. Ranajit Guha and Gayatri Chakravorty Spivak, Oxford university press, 1980)-“The voice of many different people who were not part of elite group, termed as Subaltern (taken from the work of Gramsci) was ignored or rendered in such a way as to ignore its specificity" (P-44). Again, the construction of social and ethnic norms and limits restrict the free play of a nation's "imagined political community" (Anderson, P-6). "Internal Racism" upholds the malicious discrimination within a nation against certain people favoring another group on the ground of perceived racial similarity/difference. It is to be mentioned that these perceived differences are political construction that is used to serve a particular group of people. Racial /ethnic differences are all manmade and not biological.

Due to the existence of such 'internal racism'(Balibar, p-46) and fractured people, "the Indian government under Jawaharlal Nehru represented in many respects a continuation of British attitudes both in form and in substance(Das, P-7) specifically due to the state's aggressive use of police and military. Post-colonial India saw revolts against the mechanism of governance and strive to achieve justice and equality for all. Herein lies the emergence of the Naxalite rebellion.

The Naxalites mostly belong to the parts of India where illiteracy, poverty and overpopulation converged. These Indian people supported Maoist political Ideology (Dixit, 2010; Sinha \& Baishnav 2012). In West Bengal, they launched an active movement in the 1960s in a village named Naxalbari(hence Naxalbari). According to Dixit, Naxal uprisings resulted from "still ineffectual" reforms carried out by the united front Government and "class and caste tensions"(Dixit, P-24). These reasons "polarized the 
agrarian classes and created an environment of confrontation" and caused the uprising (Das, P-25). The genesis can also be "traced to the split in 1967 of the communist party of India (Marxist) leading to the formation of communist party of India Marxist- Leninist" (Mishra, P$\mathrm{v})$. The spirit of the revolt was "in essence socio-economic and politically charged due to the spirit of the law remained confined to paper and people were left to languish"'(Das, P23).

According to Marcus Franda, "unlike most other areas of West Bengal, where peasant movements are led almost solely by middle class leadership from Calcutta, Naxalbari has spawned an indigenous agrarian reform leadership led by the lower classes including tribal cultivators "(Franda, P153). The prime cause of such struggle was the deep-seated oppression of the landless peasants and casual farmworkers. Yet the Indian Government considered it as a "law and order problem" (Dixit, P-22). Police were "empowered to combat Naxals". Dixit has observed that "in spite of the government's muscle power and legal teeth the Naxal movement has continued to spread its base because the rural and oppressed identify with its ideology" (P-23).

Draupadi is a short story, first appeared in Agnigarva (womb of fire), a collection of thinly connected politically resonated short stories. In the introductory part, Mahasweta Devi clearly encapsulates her objective behind her writing -

"life is not mathematics and the human being is not made for the sake of politics. I want a change in the present social system and do not believe in mere party politics (Agnigarva, Calcutta, 1978, p -8).

Draupadi encompasses the writer's belief in social change. Draupadi, a story of a tribal woman, is set against the turbulent political period of the 1970s. in its fictive setting, it epitomizes the Indian government's/state's aggressive response to the uprising. In the narrative, we can see how the rebellious citizens were crushed, incarcerated and terrified by state machinery as part of its biopolitical tactics. Placing a woman in the centre stage, the narrative unfolds the account of torture and killing in the name of keeping law and order intact. Focussing the state's repressive acts against the Naxalites the story narrates their grievances and experience of the state's collusion with the filthy wealthy landowner, moneylender and the state's apathy to the suffering mass.

\footnotetext{
"well, action still goes on. Moneylenders, landlords, grain brokers, anonymous brothel keepers, exinformants are still terrified. The hungry and naked are still defiant and irrepressible" (Trans. by Spivak, P396).
}

The tribal as well as non-tribal peasants, the educated and uneducated youths and the earnest believer in equal opportunity for all, actively supported and took part in the uprising. The disadvantaged section joined the comrades to see the end of the existing economic oppression.

"By the Indian constitution, all human beings, regardless of caste or creed, are sacred. Still accidents like this do happen"(Trans. By Spivak, 392)
Although the story of Dopdi/Draupadi Mejhen, the principal character, covers a span of six years, the bare event of the story happens within less than 24 hours from evening to next morning. The past events have evoked in the mind of Dopdi who keeps walking to reach Jharkhani forest to meet her fellow Naxalites. Someone is calling Dopdi by her name from back intermittently but she consciously continued her walk avoiding the call as she has taken another name to hide her real identity. Through her psychological movement readers are allowed to peep into her journey from a simple innocent life to her transformation into a dreadful Naxaliteto whom govt. has announced head-price.

\begin{abstract}
"Dopdi was proceeding slowly, with some rice knotted into her belt Mushai Tudu's wife had cooked her some. She does so occasionally. When the rice is cold, Dopdi knots it into her waistcloth and walks slowly. As she walked, she picked out and killed lice in her hair"(Trans. By Spivak, P-396-97)
\end{abstract}

Through her remembrance, she intensely connects herself with Naxalite ideology. Her concerns over the safety and security of her fellow comrades and poor Santhal villagers from the wrath of Govt., machinery and her awareness of the state's offer of a bribe to the non-loyal members to break the chain of secrecy brings to the fore the indirect play of biopolitics.

"Mushai Tudu's wife looked down. Tudu says that Sahib has come again. If they catch you, the village, our huts...

They will burn again.

...

Shomai and Budhna betrayed us" (Trans. by Spivak, P397)

But it was her capturing and "mak(ing) her up" that constitutes the direct implementation of biopolitics over her body. State's repressive action gets reflected in the strategic targeting of people to curb the uprising.

The story, divided into three parts, gradually unfolds the tensed atmosphere of Bengal particularly the districts of Birbhum, Burdwan Murshidabad and Bankura making a reference to the deployment of the army and its activities and "the people who are suspected of attacking police stations, stealing guns... killing grain brokers, landlords, money lenders, law offenders and bureaucrats" (P-393). The sample provided as the cause of clashing is getting access to the use of water during drought.

"Surja Sahu arranged with Biddibabu to dig two tube wells and three wells within the compound of his two houses. No water anywhere, draught in Birbhum. Unlimited water at surja sahu's house, as clear as a crow's eye." (Trans. by Spivak, P-398)

State's callousness to address the cause of unrest foment the trouble and eventually, it spread uniting the sufferers. State's allegiance with the oppressor(i.e.- landlord, moneylender, grain broker) along with an indifferent attitude towards the oppressed and killing the rebellious Santhals disregarding their causes of rebellion made the situation grim. 
The story, presented through the experience of a subaltern Dopdi Mejhen, discloses the aims and dealings of the states with the present circumstances giving a symbolic publicity/priority to the Naxalite movement. The state took tactics to offer financial and social security to the non-loyal members to betray the comrades and help security forces (Kennedy and Purushottam, 2012). Dopdi awakens to the fact that Shomai and Budhna betrayed her and colluded with Senanayak to apprehend her. It lays bare the state's strategy to use this moral weakness of human beings to win over the situation. But if care was taken to win the hearts of these poor men then certainly there was no need to take up arms against the state. Before being caught Dopdi is steeling herself not to disclose anything either of Mushai Tudu and her fellow comrades. "I swear by my life, by my life Dulna, by my life, nothing must be told." (Trans. by Spivak, P-397)

She is captured due to the betrayal of Shomai and Budhna. She was taken to the camp and tied to posts. After the initial failure to extract information Army resorted to violent methods to get information. The spectacle of tying Dopdi to four posts alludes to tethering animals. This shows how the detainees are dehumanised. Dopdi is sexually exploited repeatedly that night in order to extract information. Her private parts became the site of violence unleashed by state apparatus. Her situation points to a case where the law does not exist. She endures violence unleashed by the army/police who are supposed to maintain peace and order.

"opening her eyes after a million light years, Draupadi,
strangely enough, sees sky and moon... trying to move,
she feels her arms and legs still tied to four posts... she
senses that her vagina is bleeding. how many came to
make her? ...

In the muddy moonlight she lowers her lightless eye, sees her breasts, and understands that, indeed, she has been made up right. Her breasts are bitten raw, the nipples torn." (Trans. by Spivak, P-401)

These lines provide testimony of the state's torture on stage. It represents the state's agility to repress the uprising using police/army. Again, in the absence of any legal aid human being is sure to lose basic human rights. Law provides legal assistance to any accused. Any accused is also protected from inhuman treatment by the law enforcement agency. No one can be punished before a trial and conviction. We see here Dopdi suffering before her trial. She is not a prisoner according to the legal system. People like Dopdi are "unnamable and unclassifiable being". Dopdi's laughter and vociferous speech before the Senanayak condemns the authorial structure/state apparatus. It also symbolically ruptures the structure.

Her, as well as her husband's experience, shows how the state is involved in biopolitics. The shoot at sight and incarceration without juridical access defines the state machinery. It is a fictive example where constitutional rights are not met and lawlessness prevails. Draupadi clearly illustrates that-"in every case the state of exception marks a threshold at which logic and praxis blur with each other"'(Agamben, P-40). This story shows how some citizens are exposed to the state of exception/status of the threshold between human and non-human. The state's dealing with its own subjects brings forth such kind of biopolitics. Again, the voice of Dopdi Mejhen, her psychological contours all point to the resistance to the play of biopolitics. It is to be noted that a fictive setting is utilized as a space to articulate history/ contemporary setup and reflect on the position of the poor and dispossessed people.

\section{Conclusion}

The internal politics gets revealed in this short story. Despite avowed steps by statesman as well as the bureaucrats, to build the nation through justice and democracy, Draupadi's violated body and soul is a formidable showcase of the nation's split appearance and the lack of holistic structural design. Due to lack of proper implementation of planning owing to multiple reasons such unhealthy situation and complex confrontation happen and Biopolitics works.

\section{References}

1. Agamben, Giorgio. Homosacer: Sovereign Power and Bare Life, Trans. By Daniel Heller-Roazen, California: Stanford University Press, 1998.

2. Anderson. Benedict, Imagined Communities: Reflections on the origins and spread of Nationalism, Verso, 1983, p-6

3. Balibar, Etienne, Wallerstein, Immanuel. Race, nation, Class Ambiguous Identities. Verso, p-46

4. Dixit R. Naxalite Movement in India: the State's Response. Journal of Defense Studies, 4(2), P-21-35

5. Foucault, Michel. The Birth of Biopolitics: Lecture at the College De France 1978-79 (G. Burchell, Trans., and M Senellart, Ed.). New York: Palgrave Macmillan, 2008.

6. Foucault, Michel. The History of Sexuality, volume 1, Robert Hurley, Trans. Newyork: Vintage Books, 1978.

7. Franda, Marcus. Radical Reading in West Bengal. Cambridge, mass., 1971, P-153.

8. Kennedy, Jonathan, Sunil Purushotham. "Beyond Naxalbari: A Comparative Analysis of Maoist Insurgency and Counterinsurgency in Independent India." Comparative Studies in Society and History, 2012;54(4):832-862. doi:10.1017/S0010417512000436.

9. Mishra RK. Naxalite- Maoist insurgency. Jaipur (India): Y King Books, 2011.

10. Nehru's speech to the Nation on the Independence Day. Tryst with destiny speech retrieved from https://www.inc.in/en/in-focus/tryst-with-destinyspeech-made-by-pt-jawaharlal-nehru

11. Oxford. The Oxford English Dictionary. Oxford, Retrieved from http://2020Lexico.com.

12. Spivak, Gayatri C." Draupadi” English and comparative Literature, University of Chicago, 1981. https://doi.org/10.7916/D8MC8XW8 